\title{
Research Article: Knowledge and adoption of bio-fertilizers by the sugarcane growers
}

Article Chronicle: Received : 10.07.2017; Accepted : 25.07.2017

KeY Words:

Bio-fertilizers, Sugarcane growers, Education, Farming experience
Author for correspondence :

\section{D.D. NIGADE}

Department of Education, College of Agriculture (VNMKV), LATURE (M.S.) INDIA

Email : dhanunigade92@ gmail.com

See end of the article for authors' affiliations

\section{D.D. NIGADE, V.B. KAMBLE AND S.G. KHOBARE}

SUMMARY : The present study was conducted with specific objectives to study the "Adoption of bio-fertilizers by the Sugarcane growers". For the study, Latur district was selected purposively from Marathwada region. As regard with the adoption of bio-fertilizers by the sugarcane growers it was observed that respondents had39.17 per cent medium level of adoption, followed by 34.17 per cent and 26.66 per cent of them had high and low level of adoption, respectively.Independent variables viz., farming experience, education, land holding, annual income, social participation, extension contact, innovativeness, economic motivation, and risk orientation were positively and highly significantly related with adoption of bio-fertilizers by the sugarcane growers, while sources of information and innovativeness were positively and significantly related with the adoption.

How to cite this article : Nigade, D.D., Kamble, V.B. and Khobare, S.G. (2017). Knowledge and adoption of biofertilizers by the sugarcane growers. Agric. Update, 12(TECHSEAR-3) : 685-687; DOI: 10.15740/HAS/AU/ 12.TECHSEAR(3)2017/685-687. 